\title{
TBAL: Technology-Based Active Learning in Higher Education
}

\author{
Yaron Ghilay $^{1} \&$ Ruth Ghilay ${ }^{2}$ \\ ${ }^{1}$ The Neri Bloomfield School of Design and Education, Haifa, Israel \\ ${ }^{2}$ Bialik School, Holon, Israel \\ Correspondence: Yaron Ghilay, the Neri Bloomfield School of Design and Education, Haifa, Israel. Tel: \\ 972-54-468-8929. E-mail: yghilay@gmail.com
}

Received: August 19, 2015

Accepted: August 25, $2015 \quad$ Online Published: September 29, 2015

doi:10.5539/jel.v4n4p10

URL: http://dx.doi.org/10.5539/jel.v4n4p10

\begin{abstract}
In many institutions of higher education worldwide, faculty members manage lessons based on information transfer whereas their students become passive listeners. According to international research, passive learning has disadvantages mainly because students do not engage in the lesson. The study introduces a new model for higher education called TBAL: Technology-Based Active Learning. It intends to face the challenge of transfer to active learning, using mobile devices in face-to-face courses. Following a research undertaken at the Neri Bloomfield School of Design and Education $(n=67)$, the new model was found to be very successful. Students, who participated in the research, reported that courses based on TBAL principles, improved their learning process, were very experiential and had a significant contribution for better participation, collaboration and teamwork.

The TBAL model was found to be applicable to courses based on text reading, in particular, but it may be also suitable for quantitative courses, subject to appropriate adjustments.
\end{abstract}

Keywords: clicker, learning, LMS, mobile, smartphone, SRS, tablet, TBAL

\section{Introduction}

The study introduces a new model called Technology-Based Active Learning (TBAL). TBAL is designed to improve learning in face-to-face courses in higher education. It enables students to become active learners and improve their learning quality. Such an improvement is a result of better studying experience and a lot of opportunities students have to participate and express themselves.

\subsection{General Background}

Traditionally, lectures in higher education consist of teachers verbally communicating information to the students, and students passively receiving and encoding it in their memories (Boyer, 1990; Michel, Cater III, \& Varela, 2009; Stewart-Wingfield \& Black, 2005). Many studies (Bonwell \& Eison, 1991; Michel et al., 2009) suggest that the passive method may not be the most effective way for students to learn. Rather, research advocates for teaching techniques that encourage students to actively engage with the material because classroom engagement has been found to promote deeper levels of thinking and better facilitate encoding, storage, and retrieval than traditional lecture (McGlynn, 2005; Peck, Ali, Matchock, \& Levine, 2006).

A common definition for active learning is as follows:

Active learning involves providing opportunities for students to meaningfully talk and listen, write, read, and reflect on the content, ideas, issues, and concerns of an academic subject (Meyers \& Jones, 1993, p. 6).

Bonwell and Eison (1991) define active learning in a similar way:

Any strategy that involves students in doing things and thinking about the things they are doing (p. 2).

In order to actively study, learning should include any technique involving students in the learning process and holding them responsible for their own learning (Bonwell \& Eison, 1991; Michel et al., 2009; Yoder \& Hochevar, 2005).

Research supports the argument that students learn best when they engage with course material and actively participate in their learning. Yet the traditional teaching model has positioned students as passive receptors into which teachers deposit concepts and information. 
Unfortunately, most students do not succeed to function as active learners unless they are provided with active learning opportunities. Active learning shifts the focus of instruction from what instructors teach or deliver to students to what they want students to be able to do with course material. When students recognize that a course involves active learning, they tend to realize that they must be active if they wish to succeed (Instruction at FSU Handbook, 2011).

Surprisingly, educators' use of the term "active learning" has relied more on intuitive understanding than a common definition. Consequently, many faculty assert that all learning is inherently active and that students are therefore actively involved while listening to formal presentations in the classroom. Analysis of the research literature, however, suggests that students must do more than just listen: they must read, write, discuss, or be engaged in solving problems. Most importantly, to be actively involved, students must engage in such higher-order thinking tasks as analysis, synthesis, and evaluation. Within this context, it is proposed that strategies promoting active learning be defined as instructional activities involving students in doing things and thinking about what they are doing (Chickering \& Gamson, 1987).

The modification of traditional lectures is one way to incorporate active learning in the classroom. Research has demonstrated, that if a faculty member allows students to consolidate their notes by pausing three times for two minutes each during a lecture, students will learn significantly more information (Penner, 1984; Ruhl, Hughes, \& Schloss, 1987).

Discussion in class is one of the most common strategies promoting active learning. If the objectives of a course are to promote long-term retention of information, to motivate students towards further learning, to allow them to apply information in new settings, or to develop thinking skills, then discussion is more effective than lecturing (McKeachie, Pintrich, Lin, \& Smith, 1986). Furthermore, research has suggested that in order to achieve such goals, faculty should know different ways and strategies for questioning and discussion (Hyman, 1980) and must create a supportive intellectual and emotional environment, encouraging students to participate (Lowman, 1984).

McKeachie and Svinicki (2014) claim that active learning has a lot of benefits, as follows:

- Students are more likely to access their own prior knowledge, which is a key to learning.

- Students are more likely to find personally meaningful problem solutions or interpretations.

- Students receive more frequent and immediate feedback.

- The need to produce forces learners to retrieve information from memory rather than simply recognizing a correct statement.

- Students increase their self-confidence and self-reliance.

- For most learners, it is more motivating to be active than passive.

- A task that one has done himself/herself or as part of a group is more highly valued.

- Student conceptions of knowledge change, which in turn has implications for cognitive development.

- Students who work together on active learning tasks learn to work with other people of different backgrounds and attitudes.

- Students learn strategies for learning itself by observing others.

The benefits of active learning are widely acclaimed in higher education. According to Guthrie and Carlin (2004), modern students are primarily active learners, and lecture courses may be increasingly out of touch with how students engage their world. Chickering and Gamson (1987) early proponents of active learning, designated "encourage active learning" as one of seven principles of good practice in higher education.

Clickers offer one approach to employing active learning in the classroom. They are more formally denoted as Student Response Systems (SRS), Audience Response Systems (ARS), or Personal Response Systems (PRS) (Johnson, 2004).

Clickers allow students to participate in classroom activities, regardless of class size and common student dynamics. These remote-like gadgets transmit individual student responses to an instructor's computer to record and even share these results directly back to the class. Instructors can also use this data to customize their lessons for each learning group (Kenwright, 2009).

Johnson (2004) describes how clickers address three of Chickering and Gamson's (1987) seven principles for good practice in undergraduate education, as follows: 
- Actively engage students during the entire class period.

- Gauge their level of understanding of the material being presented.

- Provide prompt feedback to student questions.

Beatty (2004) claims that clickers help students actively engage in the learning process. This engagement helps students developing a more solid, integrated and useful understanding of concepts and their applicability. Clickers can provide benefit, however, when compared to some active learning methods such as class discussion. In a typical class discussion situation, only one or two students have the opportunity to answer a question. Even if the answer is correct, the instructor has no way to gauge if the other students knew the correct answer. SRS helps to overcome such difficulties. Another benefit of clickers over traditional active learning methods is that they follow the principles of game-based learning. Students of the twenty-first century have grown up using computer games for learning and entertainment (Martyn, 2007).

As mentioned above, clickers might be an effective means for creating active learning. However, in recent years, two major developments took place simultaneously. One important phenomenon is a dramatic improvement of Learning Management Systems (LMS) like Moodle. At the same time, mobile devices became very advanced and tremendously widespread. Nowadays, students in higher education have either a smartphone or a tablet, laptop or a combination of them. These sophisticated devices, while connected to an innovative LMS or other web-based applications, might function as perfect clickers, better than what existed in the previous generation. Moreover, a constant improvement occurs by updating and improving the site course, the LMS or the mobile devices and their applications. Based on this principle, it is easy and very effective to transform any regular class to a technology-based one, encouraging the existence of active learning environment.

Instead of just lecturing in front of passive students, TBAL expects to create a series of activities, in which all students take part. The research undertaken at the Neri Bloomfield School of Design and Education, intended to examine the model's effectiveness.

\subsection{Description of the TBAL Model}

TBAL intends to significantly improve the learning process in face-to-face courses based on text reading, by using students' private mobile devices. It has the following characteristics:

1) Creating an environment of active and experiential learning.

2) Enabling every student to participate in choosing a preferred technological device.

3) Creation of collaboration and teamwork.

4) Linking everyone to what takes place in class.

5) Creating lots of opportunities to all students to actively participate and express themselves.

In TBAL, every student should come to class with either a private smartphone or tablet or laptop. All devices should be linked via the institute's Wi-Fi network (or student private $3 \mathrm{~g} / 4 \mathrm{~g}$ mobile network) to the institutional LMS or to other web-based applications.

The course is based on a website built in LMS (such as Moodle), including the following components:

1) All course texts are presented on the website, divided to main topics. They comprehensively cover the whole course curriculum.

2) Each main topic is divided to subtopics, one of which includes a few activities. Each activity includes a short text taken from the course syllabus and an open-ended question. Such activities are introduced via tools like Moodle "Chat room" or equivalent, enabling all students to answer simultaneously while watching all answers appearing on the main screen. Answers can be given by every student who belongs to the course web site via any mobile device.

Before the lesson begins, each activity is hidden and it is shown to students only when its turn arrives. Students can read the text and the question either on the class main screen or on their own device. When they start answering the question, the instructor can show their responds on the main screen in real time, including their names. While answers start being presented on the main screen, the lecturer is about to refer to them by adding oral explanations, questions or relevant assessments. Such an activity encourages students to participate, express their views or ask questions either orally or in writing. Moreover, the instructor can turn to those who did not react yet in order to encourage them to be active.

3) When each subtopic is finished, students are given a short computerized quiz including a few closed questions 
covering the specific subtopic. Such an option is feasible via Moodle "Quiz" or an equivalent tool. During that activity, students can also give answers using their private device, although their answers and scores can only be viewed by the lecturer. At the end of the quiz, each student gets an automatic grade. That score can be informational only or can be weighed in the total course score. The instructor can determine a time limit and even allow students to have more than one answering trial if needed. After finishing answering, the lecturer can explain each question.

4) At the end of each main topic, students are given a more detailed computerized quiz including closed questions covering all subtopics relating to the main topic. Such a quiz can be time limited, undertaken in class or at home and its score may be informational only or not, subject to the instructor's decision.

5) At the end of the course, students have to answer a final computerized test undertaken at the institution. This exam is a significant component of the final course score. Before that examination, all activities mentioned above are shown in the course website so all learners can repeat the material using any device they wish (at home, it might be more convenient to use a PC or tablet rather than a smartphone).

\section{Method}

\subsection{The Study Framework: Examining the TBAL Model}

Students' perceptions towards TBAL were examined during a study undertaken at the Neri Bloomfield School of Design and Education.

The study examined 67 students studied in the fourth year of the Department of Business Management and participated in the course "Strategic Management". The course included the following nine main topics: introduction, the mission statement, external assessment, internal assessment, strategies in action, strategy analysis and choice, strategy implementation (two main topics) and strategy evaluation.

The course was given during the first semester of 2013-2014 and 2014-2015 and was based on the new model. It included four academic hours per-week.

\subsection{The Research Questions}

The following research questions intended to measure the effectiveness of the new TBAL model according to students' views:

1) Based on students' perceptions, does TBAL improve the learning process of face to face courses in higher education?

2) If so, what are the other characteristics of such learning and are they correlated with the improvement of the learning process?

\subsection{Population and Sample}

Population: The population addressed through the study included all higher-education students studying in courses based on the new TBAL model.

Samples: Sample 1: year 2013-14-32 students.

Sample 2: year 2014-15-35 students.

Overall: 67 students.

Students were asked to answer a questionnaire at the end of each course, concerning their perceptions towards the new model.

The questionnaire was anonymous, and the rate of response was $100 \%$.

\subsection{Tools}

In order to answer the research question, a questionnaire, including 25 closed statements and one open ended was prepared. For each question, respondents were requested to mention their views on the following Likert five-point scale:

1) Strongly disagree.

2) Mostly disagree.

3) Moderately agree.

4) Mostly agree.

5) Strongly agree. 
The open-ended question was designed to accomplish the main data gathered from the quantitative part of the questionnaire, as follows:

Do you have any other comments? Was the Technology-Based Active Learning helpful in your studying during the course Strategic Management?

\subsection{Data Analysis}

In order to examine the validity of the questionnaire, the factors' reliability was calculated (Cronbach's alpha). Based on the reliability found, the following six factors were created, as follows:

1) Improvement of the learning process by using technology: degree of technology influence on activity and improving learning, being more prepared for the final exam, the ability to better deepen the material and the creation of significant learning.

2) Successful learning experience: technology influence on activity and learning quality, satisfaction with the learning experience, the degree of enjoyment, interest and motivation to study.

3) Student choice of technological equipment: the opportunity to choose any device that students wish to use and its contribution to integration.

4) Collaboration and teamwork: cooperation among students, teamwork, collaboration influence on learning and influence of feedback given from both the lecturer and colleagues.

5) Link to the lesson: the extent by which students are engaged in the classroom and are concentrating on what is happening there.

6) Students' opportunities to participate: the influence of technology usage on students' opportunities to participate.

Table 1 presents all the factors, the reliability (Cronbach's alpha) and the questionnaire's questions composing the factors.

Table 1. Factors and reliability

\begin{tabular}{ll}
\hline Factors & Questionnaire's questions \\
\hline $\begin{array}{l}\text { Improvement of the learning } \\
\text { Alpha }=0.810\end{array}$ & $\begin{array}{l}\text { Using technology in class causes me to be active and therefore to study } \\
\text { better. }\end{array}$ \\
& $\begin{array}{l}\text { Integration of technology with a lecture enables me to study better than } \\
\text { just listening to the lecturer. }\end{array}$ \\
& Active learning based on technology is helpful for being ready for the \\
& final exam. \\
& Integration of technology enables me to deepen the material during the \\
lesson. & The use of technology has a contribution for significant learning. \\
\hline Successful learning experience & $\begin{array}{l}\text { Learning through technology is better than passive learning and } \\
\text { listening to a lecturer. }\end{array}$ \\
& The use of technology during the lesson enables me to be active. \\
& The use of technology during the lesson creates a better learning \\
experience. & I enjoy learning with technology. \\
& The use of technology makes the lesson more interesting. \\
& The use of technology increases my motivation to study. \\
& The use of technology causes me to be active in class.
\end{tabular}

Student choice of technological The choice between a smartphone, tablet or laptop allows any student equipment to integrate.

Alpha $=0.725$

The opportunity to choose the device I will use in the classroom makes it easier on me and contributes to flexibility. 


\begin{tabular}{|c|c|}
\hline \multirow{6}{*}{$\begin{array}{l}\text { Collaboration and teamwork } \\
\text { Alpha }=0.755\end{array}$} & $\begin{array}{l}\text { The use of technology allows the creation of cooperation among } \\
\text { students and teamwork. }\end{array}$ \\
\hline & $\begin{array}{l}\text { Collaborative learning through technology allows me to learn better } \\
\text { than in a normal class. }\end{array}$ \\
\hline & $\begin{array}{l}\text { Collaborative learning through technology allows me to learn from } \\
\text { friends. }\end{array}$ \\
\hline & $\begin{array}{l}\text { Collaborative learning through technology allows me to get feedback } \\
\text { in real time from the lecturer. }\end{array}$ \\
\hline & $\begin{array}{l}\text { Collaborative learning through technology allows me to get real-time } \\
\text { feedback from colleagues. }\end{array}$ \\
\hline & Displaying the answers of all students helps me. \\
\hline Link to the lesson & $\begin{array}{l}\text { Active learning through technology leads me to be constantly } \\
\text { "connected" during the whole lesson. }\end{array}$ \\
\hline \multirow{2}{*}{ Alpha $=0.742$} & Active learning through technology improves my concentration. \\
\hline & $\begin{array}{l}\text { Active learning through technology makes me constantly busy with } \\
\text { thinking related to the topics of the lesson. }\end{array}$ \\
\hline $\begin{array}{l}\text { Students' opportunities to } \\
\text { participate }\end{array}$ & $\begin{array}{l}\text { The use of technology allows all students to participate and express } \\
\text { themselves. }\end{array}$ \\
\hline Alpha $=0.732$ & The use of technology makes it easier for shy students to participate. \\
\hline
\end{tabular}

For each factor, a mean score was calculated (including standard deviation). The following statistical tests have been undertaken as well $(\alpha \leq 0.05)$ :

1) Independent Samples T-test: in order to check significant differences of factors' means between 2013-2014 and 2014-2015.

2) Paired Samples T-test: it was conducted in order to check if there are significant differences between all pairs of factors.

\section{Results}

Students were asked about the six issues mentioned above, characterizing TBAL.

There was no significant difference between the two courses (2013-2014 and 2014-2015) concerning the mean scores of all factors examined (T-test, $\alpha \leq 0.05$ ). It means that there was a replication of the results found in the first year (2013-2014) also in the second (2014-2015). It strengthens the findings and gives them more validity. Consequently, Table 2 presents the mean scores of both years together and the Independent Samples T-test, showing that the differences between these courses are not significant:

Table 2. Factors' mean scores and standard deviation

\begin{tabular}{llcccc}
\hline $\begin{array}{l}\text { Research } \\
\text { question }\end{array}$ & Factor & $\mathrm{N}$ & Mean & $\begin{array}{c}\text { Std. } \\
\text { Deviation }\end{array}$ & Independent Samples T-test \\
\hline 1 & Improvement of the learning process & 67 & 4.49 & .49 & $t_{(65)}=.079, p=.937$ \\
2 & Successful learning experience & 67 & 4.64 & .47 & $t_{(65)}=.205, p=.838$ \\
& Student choice of technological equipment & 67 & 4.58 & .59 & $t_{(65)}=.052, p=.959$ \\
& Students' opportunities to participate & 67 & 4.53 & .58 & $t_{(65)}=-.019, p=.985$ \\
& Link to the lesson & 67 & 4.51 & .50 & $t_{(65)}=.031, p=.975$ \\
& Collaboration and teamwork & 67 & 4.32 & .54 & $t_{(65)}=.310, p=.758$ \\
\hline
\end{tabular}




\subsection{The First Research Question}

The first research question was focused on exploring the hypothesis that TBAL improves the learning process of a face to face course. The first result definitely confirms that assumption, namely, according to students' perceptions, the factor "improvement of the learning process" is ranked with a very high score (4.49). The meaning of that finding is that according to students' views, a course based on the new model has a significant influence on improving the learning process.

The open-ended question strengthens the closed items relating to the first factor. Students stress that TBAL has a substantial positive influence on their learning, but the effectiveness of the process depends on a lecturer's specific skill. The following students' quotes illustrate this notion:

"Learning with technology has a significant contribution to my learning. The opportunities to have a quiz summarizing a topic and to get feedback, gives an excellent indicator for my understanding of the course contents. In case I did not succeed, I can ask the lecturer during the lesson and understand my mistake".

"Using technology during the lessons was very helpful for my learning. The process was extremely effective because the lecturer is an expert in educational technology and he keeps continuously developing this field. Therefore, technology is tremendously helpful for me to understand the course contents".

"Generally speaking, lesson management based on technology demands a lecturer having a special character, especially being very flexible. The lecturer's skill is to manoeuvre during the lesson between online exercises and oral questions and discussion. Such courses require an assertive and agile lecturer, proficient in the subject and one who can answer rapidly. The lecturer should have a personal commitment to the students in such a course, if and when they do not attend the class".

\subsection{The Second Research Question}

The second research question intended to find out additional important characteristics of TBAL and to examine if they are correlated with the first factor (improvement of the learning process). According to Table 2 (second research question), students rate all the next 5 TBAL's factors with very high scores as well. All these factors were ranked as follows: successful learning experience (4.64), student choice of technological equipment (4.58), students' opportunities to participate (4.53), link to the lesson (4.51) and collaboration and teamwork (4.32).

A paired sample T-test $(\alpha \leq 0.05)$ examined all possible 10 combinations of pairs relating to these five factors. It was found out that there are no significant differences among these factors except the following five pairs:

- Successful learning experience (4.64) and collaboration and teamwork (4.32): $t_{(66)}=6.021, p=.000$.

- Student choice of technological equipment (4.58) and collaboration and teamwork $t_{(66)}=3.424, p=.001$.

- Link to the lesson (4.51) and collaboration and teamwork (4.32): $t_{(66)}=-2.893, p=.005$.

- Students' opportunities to participate (4.53) and collaboration and teamwork (4.32): $t_{(66)}=-3.004, p=.004$.

- Successful learning experience (4.64) and Link to the lesson (4.51): $t_{(66)}=2.154, p=.035$.

Table 3 presents Pearson correlations between the factors of the second research question and the first one:

Table 3. Second research question factors' correlation with the first research question factor (improvement of the learning process)

\begin{tabular}{lccc}
\hline Factor (second research question) & Pearson Correlation & Significance & N \\
\hline Successful learning experience & .861 & .000 & 67 \\
Student choice of technological equipment & .778 & .000 & 67 \\
Students' opportunities to participate & .670 & .000 & 67 \\
Link to the lesson & .477 & .000 & 67 \\
Collaboration and teamwork & .584 & .000 & 67 \\
\hline
\end{tabular}

The findings mentioned above may provide a possible clue for a hypothetical influence of these five factors on student learning. The learning experience of TBAL is perceived to be very successful for students (4.64, Table 2) and according to Table 3, it has also a tremendous positive and significant correlation with the factor 
"improvement of the learning process" (Pearson correlation $=.861, \mathrm{p}=.000$ ). Although correlation is not necessarily a proof of a causal link, it might give an indication of the link between these variables. Similar high positive and significant correlations exist concerning all the next four factors presented in Table 3 and the factor "improvement of the learning process" (correlations' range is .477-.778, $\mathrm{p}=.000$ ). It should be mentioned that a correlation coefficient which is above .4 is considered to be high (Sarid \& Sarid, 2006). All these factors have got high scores as well, namely, they are also perceived to be very successful.

\section{Discussion}

Unfortunately, in many institutions of higher education worldwide, faculty members manage lessons based on information transfer whereas their students become passive listeners (Boyer, 1990; Michel, Cater III, \& Varela, 2009; Stewart-Wingfield \& Black, 2005). According to international research, passive learning is problematic mainly because students are not engaged in the lesson and in many cases, lots of them are disconnected from what takes place in class (Bonwell \& Eison, 1991; Michel et al., 2009). On the other hand, the research stresses that teaching styles, encouraging active learning are much better and lead to better achievements (McGlynn, 2005; Peck, Ali, Matchock, \& Levine, 2006). Although there is no controversy relating to active learning advantages, its implementation in class is not straightforward. It seems that faculty members face barriers while trying to transfer from traditional to active learning. In order to overcome these barriers, the study introduces a new model called TBAL (Technology-Based Active Learning) which helps lecturers to create an active environment in their class. The model simplifies the practical procedures of converting traditional learning to active studying.

According to the study's findings, TBAL has been found to be very helpful, providing faculty members with a practical tool assisting them to transfer to the active world of learning. Students who studied courses based on the new model, reported that it substantially improved their learning process. One of the prominent findings points out that they had a special and unique learning experience which is totally different compared to traditional learning. Moreover, students claimed that they had many opportunities to participate, they have been completely concentrated and linked to the lessons and collaboration and teamwork have been significantly improved as well.

One of the great benefits of the new model is that it does not necessarily require new expensive hardware or software. It mainly depends on existing smartphones (or tablets/laptops) which in the twenty-first century, most students have. This equipment should be linked to a learning management system such as Moodle, existing in most higher education institutions as well. The additional necessary condition is to have lecturers who are familiar with the management of online courses and well know the TBAL model. Training of lecturers to successfully manage online courses in higher education can be achieved based on the TMOC model (Training to Management of Online Courses), introduced by Ghilay and Ghilay (2014).

It should be stressed that in order to practically create an effective course based on TBAL principles, it is required to effectively combine technological and pedagogic qualifications. The technological ability is a necessary and an insufficient condition for effective technology-based active learning. Only a combination of both technological and pedagogical capabilities is necessary and sufficient for effectively conducting this kind of learning.

The study examined a course based on the new model during the academic years 2013-14 and 2014-15. The significant quantitative findings show that students perceived it as a very effective tool for the creation of an active learning environment which significantly improves their learning. The qualitative data gathered, strengthens the quantitative part and gives it more validity. The new model was found to be applicable in particular to courses based on text reading. Nevertheless, it might be suitable for quantitative courses as well, subject to appropriate adjustments.

Because TBAL has a major contribution to learning improvement, it is recommended to adopt it in institutions of higher education worldwide.

\section{References}

Beatty, I. (2004). Transforming student learning with classroom communication systems. EDUCAUSE Centre for Applied Research, Research Bulletin, 3, 5.

Bonwell, C., \& Eison, J. (1991). Active learning: Creating excitement in the classroom. ASHE-ERIC Higher Education Report No. 1, Washington, D.C.: The George Washington University, School of Education and Human Development. 
Boyer, E. (1990). Scholarship reconsidered. New York: The Carnegie foundation for the Advancement of Teaching.

Chickering, A. W., \& Gamson, Z. F. (1987). Seven principles for good practice. AAHE Bulletin, 39, 3-7.

Ghilay Y., \& Ghilay, R. (2014). TMOC: A model for lecturers' training to management of online courses in higher-education. Journal of Educational Technology, 11(2), 6-16.

Guthrie, R. W., \& Carlin, A. (2004). Waking the dead: Using interactive technology to engage passive listeners in the classroom. Proceedings of the Tenth Americas Conference on Information Systems, New York.

Hyman, R. T. (1980). Improving discussion leadership. New York: Columbia Univ., Teachers College Press.

Instruction at FSU Handbook. (2011). A guide to teaching and learning practices. The Florida State University.

Johnson, C. (2004). Clickers in your classroom. Wakonse-Arizona E-Newsletter, 3(1).

Kenwright, K. (2009). Clickers in the classroom. TechTrends, 53(1), 74-77. http://dx.doi.org/10.1007/s11528-009-0240-7

Lowman, J. (1984). Mastering the techniques of teaching. San Francisco: Jossey-Bass.

Martyn, M. (2007). Clickers in the classroom: An active learning approach. Educause Quarterly, 2, 71-74.

McGlynn, A. P. (2005). Teaching millennials, our newest cultural cohort. Educational Digest, 12-16.

McKeachie, W. J., \& Svinicki, M. (2014). Teaching tips: Strategies, research, and theory for college and university teachers. Boston: Houghton Mifflin.

McKeachie, W. J., Pintrich, P. R., Lin, Y. G., \& Smith, D. A. F. (1986). Teaching and learning in the college classroom: A review of the research literature. Ann Arbor: Regents of the Univ. of Michigan.

Meyers, C., \& Jones, T. B. (1993). Promoting active learning: Strategies for the college classroom. San Francisco: Jossey-Bass.

Michel, N., Cater III, J. J., \& Varela, O. (2009). Active versus passive teaching styles: An empirical study of student outcomes. Human Resource Development Quarterly, 20(4), 397-418. http://dx.doi.org/10.1002/hrdq.20025

Peck, A. C., Ali, R. S., Matchock, R. L., \& Levine, M. E. (2006). Introductory psychology topics and student performance: Where's the challenge? Teaching of Psychology, 33(3), 167-170. http://dx.doi.org/10.1207/s15328023top3303_2

Penner, J. G. (1984). Why many college teachers cannot lecture. Springfield, Ill.: Charles C. Thomas.

Ruhl, K. L., Hughes, C. A., \& Schloss, P. J. (1987). Using the pause procedure to enhance lecture Recall. Teacher Education and Special Education, 10, 14-18. http://dx.doi.org/10.1177/088840648701000103

Sarid, M., \& Sarid, Y. (2006). The guide for SPSS for windows. Sarid Institute Publication-Research and Training Ltd (in Hebrew).

Stewart-Wingfield, S., \& Black, G. S. (2005). Active versus passive course designs: The impact on student outcomes. Journal of Education for Business, 81, 119-125. http://dx.doi.org/10.3200/JOEB.81.2.119-128

Yoder, J. D., \& Hochevar, C. M. (2005). Encouraging active learning can improve students' performance on examinations. Teaching of Psychology, 32(2), 91-95. http://dx.doi.org/10.1207/s15328023top3202_2

\section{Copyrights}

Copyright for this article is retained by the author(s), with first publication rights granted to the journal.

This is an open-access article distributed under the terms and conditions of the Creative Commons Attribution license (http://creativecommons.org/licenses/by/3.0/). 